\title{
Global literature of fiddler crabs, genus Uca (Decapoda, Ocypodidae): trends and future directions
}

\author{
João C. Nabout ${ }^{1}$, Luis M. Bini ${ }^{2}$ \& José A. F. Diniz-Filho² \\ 1. Departamento de Ciências Biológicas, Universidade Estadual de Goiás, Unidade Universitária de Ciências Exatas e Tecnológicas \\ (UnUCET), BR 153 Km 98, Cx. Postal 459, 75074-840, Anápolis, GO, Brasil. (naboutjc@pq.cnpq.br) \\ 2. Laboratório de Ecologia teórica e síntese, Departamento de Ecologia, Universidade Federal de Goiás, Campus II, Goiânia, GO, Brasil.
}

\begin{abstract}
Crabs of the genus Uca Leach, 1814 are characterized by having strong sexual dimorphism and a global distribution. Currently, 97 species have been described and analyzed under several aspects, including population ecology, physiology and ethology. However, there is no general summary of the information from the various literatures. The aim of this study is to perform a scientometric analysis of fiddler crab studies. For this we searched papers available in the Thomson ISI database that contained the words "Uca" OR "fiddler* crab*" between the years 1991 and 2007. For each paper, we researched and recorded the following characteristics: publication year; journal of publication; the first author's nationality; the country where the study was conducted; study type; species studied; and the work area. Our results indicated that there was no increase in the number of articles through the years considered. The Journal of Experimental Marine Biology and Ecology published most of the articles on Uca, indicating the importance of this group as a model for testing ecological hypotheses using experimental approaches. Our results also showed that United States had the highest number of authors and published studies on Uca, following the overall trend in dominance on scientific research. Furthermore, using models with three variables (per capita income, number of species of $U c a$ and extent of coastal countries) we observed that, according to the Akaike Information Criterion, the per capita income was the most important correlate for the number of articles per country (both the author's country and country of study). Additionally, our results show that the species U. pugilator (distributed on the East Coast of the North American continent) was the species most singularly referenced in the papers considered. Moreover, our results indicate that most studies on Uca use a descriptive and local scale. The majority of papers in our literature search reflect studies in population biology, followed by behavioral and physiological characteristics.
\end{abstract}

KEYWORDS. Scientometrics, population biology, Uca pugilator, AIC, Per capita income.

RESUMO. Literatura global sobre caranguejos violinistas, gênero Uca (Decapoda, Ocypodidae): tendências e direções futuras. Caranguejos do gênero $U c a$ Leach, 1814 são caracterizados por apresentarem forte dimorfismo sexual e são globalmente distribuídos. Atualmente são descritas 97 espécies desse gênero, sendo estudados em diversos aspectos como ecologia de populações, fisiologia e etologia. Entretanto, até o presente não existe um trabalho que sintetize as informações da literatura científica sobre esse grupo. O objetivo desse trabalho foi realizar uma análise cienciométrica sobre estudos de caranguejo Uca. Para isso, buscou-se artigos que continham os termos "Uca" OR "fiddler* crab*, entre 1991 e 2007, disponíveis na base de informações bibliográficas do Thomson ISI. Para cada artigo foram coletadas informações como ano de publicação, periódico onde o artigo foi publicado, nacionalidade do primeiro autor, país onde o trabalho foi desenvolvido, tipo de estudo, espécie estudada e área do trabalho. Os resultados obtidos indicaram que não houve incremento no número de artigos ao longo dos anos. A revista que apresentou o maior número de artigos sobre Uca foi o Journal of Experimental Marine Biology and Ecology, indicando a importância desse grupo como modelo para o teste de hipóteses ecológicas com o uso de abordagem experimental. Os Estados Unidos foi o país que apresentou maior número de autores que publicaram sobre $U c a$ e também o país com o maior número de trabalhos sobre $U c a$. Possivelmente isso deveu-se ao maior investimento em infra-estrutura e pesquisa nesse país. Além disso, usando modelos com três variáveis preditoras (renda per capita, número de espécies de Uca e extensão costeira dos países) observou-se que de acordo com o Critério de Akaike a variável renda per capita foi a mais importante para explicar o padrão do número de artigos por país (i.e. país do autor e país de estudo). A espécie que apresentou o maior número de trabalhos desenvolvidos foi $U$. pugilator, essa espécies distribuí-se na costa leste do continente Norte Americano. Além disso, a maior parte dos trabalhos sobre Uca foi de cunho descritivos e em escala local. Quanto a área do trabalho, grande parte dos artigos esteve inserido na categoria populacional, seguido de comportamental e fisiológico.

PALAVRAS-CHAVE. Cienciometria, biologia de populações, Uca pugilator, AIC, renda per capita.

Coastal marine environments have long attracted interest in the scientific community, arguably due to the high species and habitat diversity (SALA \& KNOWLTON, 2006). Moreover, coastal environments of the world are economically and socially important (COSTANZA et al., 1997) and, thus, have been threatened by various human activities that trigger habitat loss and species extinctions (MANN, 2000; HARLEY et al., 2006).

It has been observed that there is an increasingly number of papers that describe new marine species (Bouchet, 2006). The coastal environments, however, when compared with other environments (e.g., forests), have fewer studies in conservation biology. Moreover, marine and coastal invertebrates are less well-studied in comparison with birds and mammals (FAZEY et al., 2005).

Among the marine species, crustaceans have high species diversity, with an estimate of more than 68,000 species (Martin \& Davis, 2006). Within this group, the genus Uca Leach, 1814 is represented by 97 species (ROSENBERG, 2001) and are characterized by having strong sexual dimorphism with asymmetry of the male (CRANE, 1975). Moreover, species of Uca are small in size and form dense populations that are distributed in many tropical regions of the world (ZEIL et al., 2006). Uca was 
first described in 1758 (see taxonomic revision in ROSENBERG, 2001) and since the mid-eighteenth-century many studies have used this taxonomic group in different research fields (e.g., population ecology, behavioral biology and physiological aspects ZeIL et al., 2006). However, there is no summary of modern research trends for $U c a$. This genus serves as a model organism for many disciplines, such as physiology (FrASER, 2006), ecology (GODLEY \& BROdIE, 2007), environmental sciences (OduM, 1969; Culbertson et al., 2007) and behavioral ecology studies (How et al., 2007). The aims of our study were: (i) evaluate the trend of the number of papers related to this genus; (ii) determine which species were the most studied; (iii) identify which subject category (areas of study) use $U c a$ as a model organism; and (iv) determine which journals, countries and authors have published more articles on Uca and compare models that explain the pattern of scientific productivity of different countries. Based on this assessment, we have identified potential directions for future research on $U c a$.

\section{MATERIAL AND METHODS}

The survey of the published literature was conducted using the Thompson ISI database with the keywords "Uca" OR "fiddler* crab*". The use of the asterisk in this search indicates that any ending of the word may be accepted, assuring inclusion of that term in the singular and plural forms.

Our study recorded the following criteria for each publication recorded: (i) publication year; (ii) journal title and the diversity of journal over the years (estimated using the Shannon index); ( iii) first author country; (iv) country where the work was developed (when possible); (v) type of study (theoretical, experimental or descriptive); (vi) species studied; and (vii) subject category (population, behavioral, physiological, morphological, environmental or genetic/evolution). Within "type of study" we classified the studies into the category "experimental", for papers that have developed an experiment in either the laboratory or field, and the category "descriptive" for papers that characterize other aspects of the population (e.g., density and environmental impact studies). The category "theoretical" includes papers that are reviews and syntheses of biological or phylogenetic information about Uca. In "subject category", papers relating to population attributes (e.g., density, distribution and ecological interactions) were classified as "population", whereas papers on the arrangement behaviors (e.g., choice of mate, fighting) were inserted in "behavioral" class; articles on physiological aspects, tolerance and relations with environmental variables (such as salinity and temperature) were classified as "physiological"; papers that presented taxonomic and morphological characteristic of genus Uca were inserted in "morphological"; articles that discussed the impacts of environmental damage to populations of the genus $U c a$ were added in category "environmental"; and genetic papers, such as analyses of genetic diversity and works that presented evolutionary patterns, were entered in category "genetic/evolution".

To evaluate yearly trends in the number of papers, it was necessary to account for the general overall trend of increase in the number of papers for the years under consideration (PETERs, 1991). To achieve this, the number of papers published each year was divided by the total number of articles found in the database for that year.

Additionally, we recorded the nationality of the author (first author), as well as the country where the study was conducted (i.e., country of study). We generated multiple regression models to explain the number of papers based on the authors' nationality and country of study. These models consisted of three explanatory variables and were compared using the Akaike Information Criterion (AIC), and the best model was given as the one for which the lowest value of AIC was found (Burnham \& Anderson, 2002). The explanatory variables used were the per capita income (in dollars), geography (coastal extension in $\mathrm{km}$ ) and biology (number of Uca species) of the respective countries (with a total of 34 countries). We created seven distinct models based on combinations of the three variables. For these models, we expect that countries with the highest number of articles - based on the authors' nationality and country of study - have a higher per capita income (sensu FAZEY et al., 2005), greater coastal geographical extension and a higher number of $U c a$ species. Data on a country's per capita income was based on 2007 data obtained from the site of the World Bank (The World Bank Data, www.worldbank.org/data, accessed on June 2, 2009).

The diversity of journals that published research on the genus $U c a$ was estimated using Shannon-Wienner index (H') for each year (MAGURRAN, 2004). Recent studies have used this index in scientometric studies to evaluate the tendency of the diversity of journals that publish on a particular subject (e.g., CARVAlHo et al., 2005; CARNEIRO et al., 2008).

\section{RESULTS}

We registered 471 papers in the database of Thomson ISI with references to the genus $U c a$, between 1991 and 2007. After accounting for an overall increase in the number of articles, the number of papers with the genus $U c a$ did not increase significantly over the years ( $\mathrm{r}=0.21, P=0.31$; Fig. 1$)$.

A total of 131 journals published papers on $U c a$, but a large portion of the papers (271 or $57 \%$ of articles) was published in only 20 journals (Fig. 2). The Journal of Experimental Marine Biology and Ecology had the largest number of articles (35, or $7.4 \%$ of total papers), followed by the Marine Ecology - Progress Series (33 articles, or $7 \%$ ). There is an increase in the diversity (measured by $\left.\mathrm{H}^{\prime}\right)$ of journals over the years $(\mathrm{r}=0.55, P=0.01)$.

Authors from the United States had the highest number of published articles about Uca (210, or $44 \%$ 
papers of total), followed by authors from Japan (47, or $10 \%$ of total), Argentina (26, or $5.5 \%$ of total), Australia (26, or $5.5 \%$ of total) and Brazil (21, or $4.4 \%$ of total). These five countries accounted for more than $70 \%$ of the total papers. Our total database consists of 34 countries (i.e. author country). In terms of the geographical location for the studies, we found that, were identified 180 studies (local of studies). These studies were distributed in 28 countries and, the largest portion os these studies were located in the United States (62, or 34\% of total papers), followed by Brazil (21, or $11 \%$ of total), Argentina (15, or $8 \%$ of total), Australia (10, or $5.5 \%$ of total) and Mozambique (9, or $5 \%$ of total).

We generated seven distinct models to explain the distribution of the papers by both the first author's nationality and by the country where the study was conducted. According to AIC, the model that better explained the number of articles by the author's country was the model that was based on per capita income and the number of species of Uca (Tab. I). Based on this model, countries with the largest number of papers (considering the nationality of authors) were those with

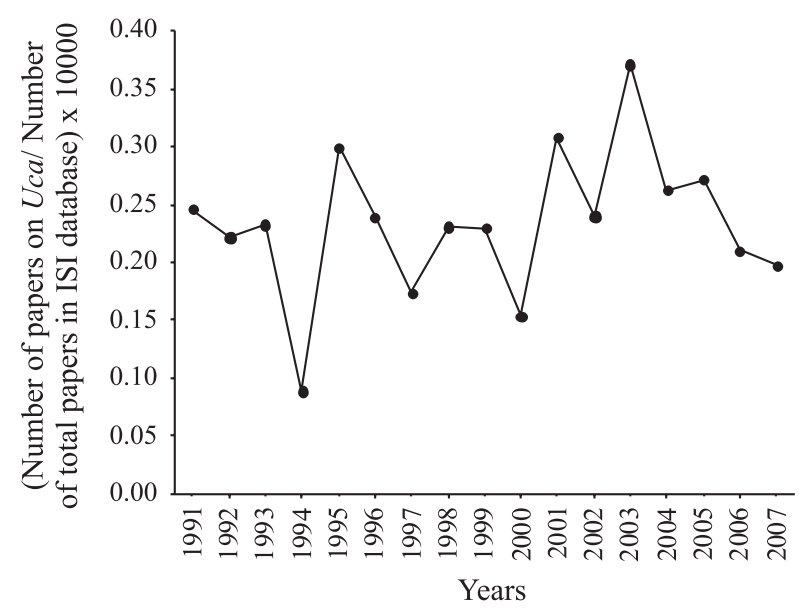

Figure 1. Temporal variation in the number of papers about genus Uca indexed in the Thomson ISI between the years 1991 and 2007. The values recorded were previously standardized (see Materials and Methods).

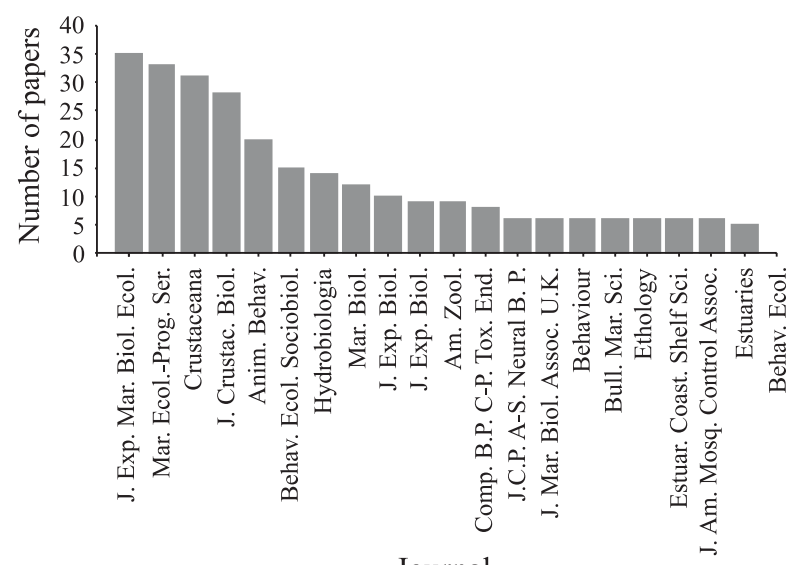

Journal

Figure 2. Journals with the highest number of articles on the genus Uca $(\mathrm{n}=471)$. both a higher per capita income and a greater number of species of $U c a$, according to the positive standardized coefficient with these variables (Tab. II). The model that better explained the number of papers by country of study, with the lowest AIC value, was composed of a single, unique variable (income per capita) (Tab. I). In addition, this variable had greater significance than the other variables considered (Tab. II).

Most of the papers surveyed were classified as descriptive (306 articles, or $64 \%$ of total), whereas experimental studies represented $24 \%$ of the total (117 articles), and few articles on Uca were classified as theoretical (48 articles or $10 \%$ ).

A large proportion of papers analyzed in this study focused on merely a few species of Uca. Most studies did not specify the species studied or analyze all species within the genus. However, in papers that explicitly stated which species was studied, we observed that $U$. pugilator (Bosc, 1802) was the most studied species (97 papers, or $17 \%$ of total), followed by U. pugnax (Smith, 1870) (42 papers, or 7\%) and U. tangeri (Eydoux, 1835) (33 papers, or $5 \%$ ) (Fig. 3).

In our analysis of the subject category, the category "population" was a broadly inclusive term that incorporated studies dealing with structure and dynamics of populations (150 papers, or $31 \%$ of total). Papers with a research emphasis on physiological and behavioral issues had 104 and 98 papers in these respective categories (Fig. 4).

Table I. Model selection results showing the seven models used to describe the number of papers by country of author $(n=469)$ and country of study $(n=180)$. For each model, consider the respective values of the coefficient of determination $\left(R^{2}\right)$ as well as the Akaike (AIC) and hierarchical classifications of the model (in parentheses) according to the lowest value of AIC. The variables are: number of species (S), income per capita (I) and costal extension $(\mathrm{C})$.

\begin{tabular}{lccccc}
\hline Models & \multicolumn{2}{c}{ Country of author } & & \multicolumn{2}{c}{ Country of study } \\
\cline { 2 - 3 } \cline { 6 - 6 } & $\mathrm{R}^{2}$ & AIC & & $\mathrm{R}^{2}$ & AIC \\
\hline S,I & 0.19 & $349.89(1)$ & & 0.26 & $198.23(3)$ \\
C,S,I & 0.21 & $351.74(2)$ & & 0.27 & $201.08(4)$ \\
C & 0.07 & $352.09(3)$ & & 0.05 & $201.52(6)$ \\
S & 0.06 & $352.41(4)$ & & 0.01 & $202.46(5)$ \\
C,R & 0.11 & $353.02(5)$ & & 0.26 & $198.04(2)$ \\
I & 0.05 & $353.08(6)$ & & 0.24 & $195.89(1)$ \\
C,S & 0.11 & $353.26(7)$ & & 0.05 & $204.36(7)$ \\
\hline
\end{tabular}

Table II. Model selection evidenced for each explanatory variable and the importance and the standardized correlation coefficient (coefficient). Variables include: Coastal extension (C), number of species (S) and per capita income (I).

\begin{tabular}{lccccc}
\hline \multirow{2}{*}{ Variables } & \multicolumn{2}{c}{ Country of author } & & \multicolumn{2}{c}{ Country of study } \\
\cline { 2 - 3 } \cline { 5 - 6 } & Importance Coefficient & & Importance Coefficient \\
\hline $\mathrm{C}$ & 0.43 & 0.22 & & 0.26 & 0.15 \\
$\mathrm{~S}$ & 0.71 & 0.35 & & 0.23 & 0.11 \\
$\mathrm{I}$ & 0.69 & 0.34 & & 0.93 & 0.48 \\
\hline
\end{tabular}




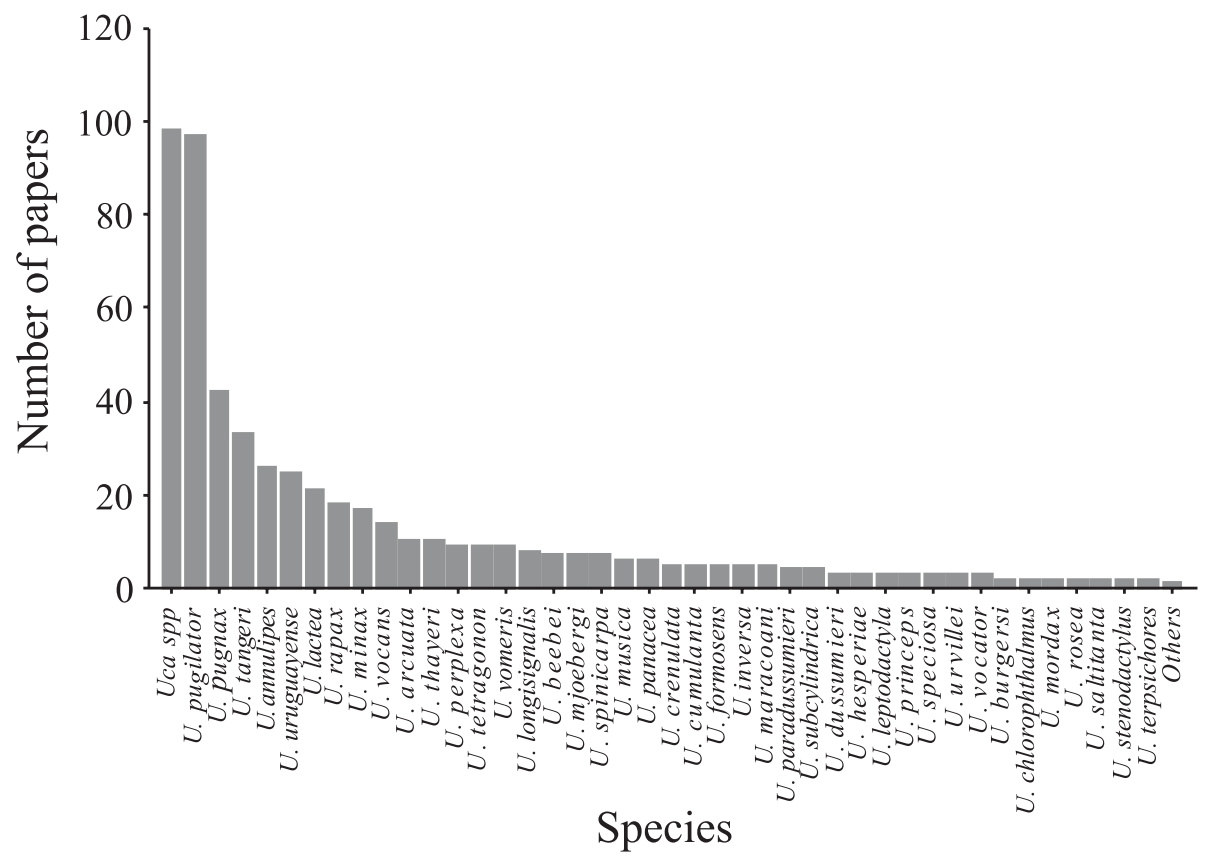

Figure 3. The number of papers about the genus $U c a$. The category "Uca spp" indicates papers that did not specify the species studied or examined all the species of the genus Uca (in taxonomic revisions). The category "other" includes species mentioned specifically in only one study, a total of 15 different species: U. bengali, U. borealis, U. capricomis, U. coloradensis, U. crassipes, U. dampieri, U. elegans, U. flammula, U. forcipata, U. hirsutimanus, U. monilifera, U. panamensis, U. polita, U. seismella and U. signata.

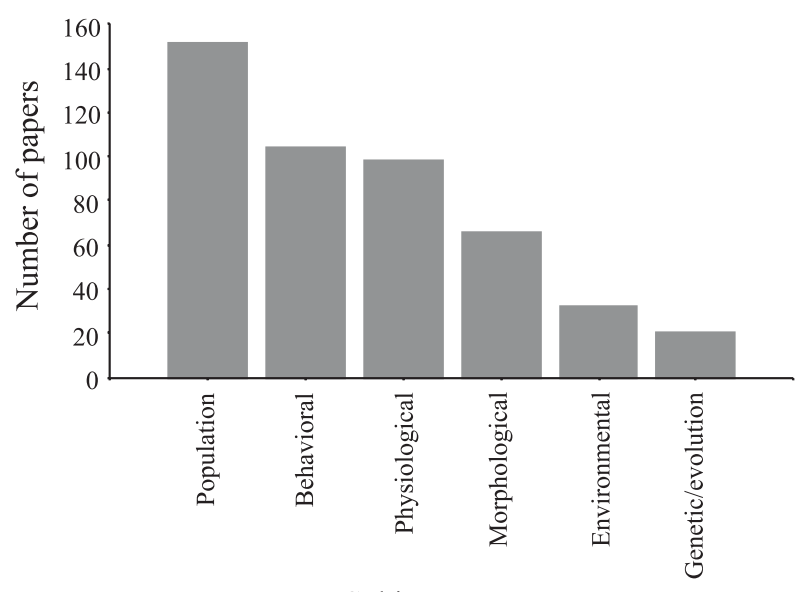

Subject category

Figure 4. The subject categories of papers about the genus Uca (see details in Material and Methods).

\section{DISCUSSION}

Recently, scientometrics analyses have been used to summarize the advances as well as detect gaps in environmental (e.g., BINI et al., 2005; FAZEY et al., 2005; FERREIRA JúNIOR et al., 2008) and ecological research (e.g., Budilova et al., 1997; Nobis \& Wohlgemuth, 2004; CARneiro et al., 2008; PAdial et al., 2008; Pinto \& Bini, 2008; BRITO et al., 2009). Scientometric studies have often shown an overall increase in the number of research papers over a particular period of time. This is demonstrated in studies of phytoplankton (CARNEIRO et al., 2008), macrophytes (PADIAL et al., 2008), population ecology (LIMA-RIBEIRo et al., 2007) and genetic studies with use of flow cytometry (QuIXABEIRA et al., 2010).
However, this study showed no significant increase in the number of papers on the genus Uca. Our result may suggest that there was not increased interest in this taxonomic group within the scientific community, or it may indicate a disinterest in international journals (indexed in Thomson ISI) in papers about this genus. However, other scientometric studies presented similar results to our study. For example, themes focusing on "taxonomy" and "estuary" showed no increase in the number of papers over the years (between 1987 and 2005) after analysis of six major reviews of limnology (WISHART \& DAVIE, 2002). Studies on the taxonomy of algae have also declined over the last three decades (IRFANULLAH, 2006).

Moreover, the number of studies of marine biodiversity has a much smaller increase when compared with studies of terrestrial biodiversity (HENDRIKS \& DUARTE, 2008). In other words, the pattern that indicates an increase in the number of papers in different areas should be evaluated carefully, as the patterns can be associated with taxonomic and geographic biases. Although the genus $U c a$ shows no increase in research interest, the genus is, nevertheless, pertinent to several research agendas. It is located in coastal marine environments and subject to strong human impact (HARley et al., 2006; HALPERn et al., 2008). Thus, we argue that these organisms can be models for studies on conservation of coastal environments as well as useful in assessing the impact of climate change on marine environments.

Another aspect of our study was an evaluation of the distribution of journals that published articles about the genus $U c a$. In general, the publication journal can be used as a criterion to evaluate the search field (MELO et al., 2006; VANTI, 2002). Papers on the genus Uca were 
more common in journals that focus on studies in marine biology and the biology of crustaceans (e.g., Journal of Experimental Marine Biology and Ecology, Marine Ecology-Progress Series, Crustaceana and Journal Crustacean Biology). However, the results of this study also showed that, over the years, there was an increasing diversity of journals that publish articles on the genus $U c a$, thus indicating that $U c a$ may be important as a model organism in other research areas (such as ethology, ecology and evolution).

Some journals of Brazil have published articles about genus Uca. Thus, a new search on Thomson-ISI, using only Journal of Brazil (all available in the ThomsomISI) revealed that between 1991 and 2009 were published 17 papers. Brazilian journals with the highest number of paper about Uca were Revista Brasileira de Zoologia (actually Zoology) (9 papers) followed by Iheringia Série Zoologia (4), Brazilian Archives of Biology and Technology (3) and Revista Brasileira de Genética (1). Theses papers of Brazilian journal have focused mainly on issues such as ecology (e.g. NABOUT et al., 2009), morphology (e.g. BezErRA \& Coelho, 2009), and population structure (e.g. BEDE et al., 2008) of Uca.

We observed that the per capita income of the country was an important variable in explaining the pattern of the number of published articles, both in terms of the authors' country of origin as well as the country of study. The United States had the largest number of authors and the highest number of $U c a$ research studies (between 1991 and 2007). The large number of articles by Americans may reflect the investment in infrastructure and research (MAY, 1997; FAZEY et al., 2005), although Latin American countries have shown large increases in scientific publications (HILl, 2004). Authors of Latin American countries (recorded as having medium and low per capita income) had a significant contribution to the pattern of global scientific publication (for example, Brazil and Argentina had more papers about $U c a$ than European countries). Additionally, the variable "number of species" of $U c a$ was an important variable to explain the number of papers in terms of an author's country, but the geographical extent of coastal countries did not explain the number of papers from those countries (authors and study) in terms of anything significant. Furthermore, while per capita income and number of species compose the best models (according to AIC), we observed that these models have a weak explanatory power, as evidenced by the low coefficients of determinations of the best models (19\% for the best model in the country the author and $24 \%$ for the best model in the country of study). Other variables, not measured in this study, may be also important to explain the number of papers from countries (e.g., the training of human resources, such as taxonomists).

A high proportion of the papers considered in this study did not indicate the specific Uca species studied or, simply, analyzed all species together. However, $17 \%$ of the papers utilized the specific species $U$. pugilator (97 articles). These studies were both experimental and descriptive and focused primarily on ecological, genetic, behavioral and morphological studies. This species, together with U. pugnax, was considering by CRANE (1975) to be the most well studied species of Uca. Both species (U. pugilator and U. pugnax) are widely distributed geographically $(10,930 \mathrm{~km}$ for $U$. pugilator and $6,067 \mathrm{~km}$ for $U$. pugnax). They have similar geographic distributions in estuaries in the North American Gulf of Mexico region (CRANE, 1975).

Several areas of biology can detect taxonomic biases (Pinto \& Bini, 2008; McCollin \& BALdi, 2003). These biases are driven mainly by economic interests on a species' endangerment and/or whether the species is considered "charismatic". In the case of $U$. pugilator, this species has no economic interest, is not listed as endangered by IUCN and, like most invertebrates, is not "charismatic" (PINTO \& BINI, 2008). Arguably, the species has been studied extensively due to its geographical distribution in the United States (the country that had the largest number of articles on $U c a$ research).

The papers about the genus $U c a$ have been mainly developed on the local scale. This result is frequent in descriptive and experimental biological studies (BALDI \& McCollin, 2003). Moreover, many studies can be classified as descriptive and experimental. Descriptive studies are common in ecological literature, primarily focusing on variables such as density and distribution of species (CARNEIRO et al., 2008). The fact that Uca are easily handled and biologically resistant (CRANE, 1975) contributed to the high frequency of studies with experimental approach.

Many Uca studies were classified as "population" and "behavioral" according papers in their subject category. Most population studies have concentrated on describing attributes of Uca populations, whereas behavioral studies have attempted to analyze their complex behavioral patterns (such as fighting and territoriality [CROLL \& MCCLINTOCK, 2000]). Considering the types of studies (descriptive, experimental or theoretical), we note that the population papers were mainly descriptive (of 151 population papers, 123 papers were descriptive).

Although there is not a significant increase in the number of papers focusing on the genus $U c a$ in current literature, there are a many options for future work with this crustacean group, such as macroecological and macroevolutionary studies focusing on a global scale of research. In addition, genetic attributes can be explored within this taxonomic group, focusing on population genetics and DNA sequences for a better understanding of phylogenetic relationships. Finally, it is essential for studies to focus on environmental infrastructure and current problems arising from human impact, such as the destruction of coastal habitats and global warming.

Acknowledgments. JCN is supported by productivity grants from Universidade Aberta do Brasil (UAB, no 0213573660). LMB and JAFDF are supported by productivity grants from Brazilian $\mathrm{CNPq}$ and by Fundação de Amparo à Pesquisa da Universidade Federal de Goiás (FUNAPE/UFG).

\section{REFERENCES}

BÁldi, A. \& McCollin, D. 2003. Island ecology and contingent theory: the role of spatial scale and taxonomic bias. Global Ecology and Biogeography 12:1-3

Bede, L. M.; Oshiro, L. M. Y.; Mendes, L. M. D. \& Silva A. A. 2008. Comparison of the population structure of the species 
of Uca (Crustacea: Decapoda: Ocypodidae) in the mangrove of Itacuruca, Rio Janeiro, Brazil. Revista Brasileira de Zoologia 25(4):601-607.

Bezerra, L. E. A. \& Coelho, P. A. 2009. Intraspecific variation in preserved specimens of the fiddler crabs Uca panacea and Uca pugilator (Decapoda: Ocypodidae). Zoologia 26(1):175-182.

Bini, L. M.; Diniz-Filho, J. A. F.; Carvalho, P.; Pinto, M. P. \& RANGel, T. F. L. V. B. 2005. Lomborg and the litany of biodiversity crisis: what the peer review literature says. Conservation Biology 20:1-6.

Bosc, L. A. G. 1802. Manuel de l'histoire naturelle des crustacés, contenant leur description et leurs moeurs; avec figures dessinées d'après nature. Volume 1. Paris, Deterville. 282p.

Bouchet, P. 2006. La Magnitud de la biodiversidad marina. In: Duarte, C. M. ed. La exploración de la biodiversidad marina: Desafíos científicos y tecnológicos. España, Fundación BBVA, p.31-62

Burnham, K. P. \& Anderson, D. R. 2002. Model selection and multimodel inference: a practical informationtheoretic approach. New York, Springer. 488p.

Brito, D.; Oliveira, L. C.; Oprea, M. \& Mello, M. A. R. 2009. An overview of Brazilian mammalogy: trends, biases and future directions. Zoologia 26:67-73.

Budilova, E. V.; Drogalina, J. A. \& Teriokhin, A. T. 1997. Principal trends in modern ecology and its mathematical tools: an analysis of publications. Scientometrics 39:147-157.

Carneiro, F. M.; Nabout, J. C. \& Bini, L. M. 2008. Trends in the scientific literature on phytoplankton. Limnology 9:153-158.

Carvalho, P.; Diniz-Filho, J. A. F. \& Bini, L. M. 2005. The impact of Felsenstein's "phylogenies and comparative method" on evolutionary biology. Scientometrics 62:53-66.

Costanza, R.; d’Arge, R.; de Groot, R.; Farber, S.; Grasso, M.; Hannon, B.; Limburg, K.; Naeem, S.; O’Neill, R. V.; Paruelo, J.; Raskin, R. G.; Sutton P. \& Belt, M. V. D. 1997. The value of the world's ecosystem services and natural capital. Nature 387:253-260.

Crane, J. 1975. Fiddler Crabs of the World (Ocypodidae: Genus $\boldsymbol{U c a}$ ). Princeton, Princeton University Press. 736p.

Croll, J. A. \& McClintock, J. B. 2000. An evaluation of lekking behavior in the fiddler crab Uca spp. Journal of Experimental Marine Biology and Ecology 254:109-121.

Culbertson, J. B.; Valiela, I.; Peacock, E. E.; Reddy, C. M.; Carter, A. \& VANDERKRUIK, R. 2007. Long-term biological effects of petroleum residues on fiddler crabs in salt marshes. Marine Pollution Bulletin 54:955-962.

Eydoux, F. 1835. Nouvelle espèce de Gélasime. Magazine de Zoologie 5:1-4

Fazey, I., Fischer, J \& Lindenmayer, D. B. 2005. What do conservation biologists publish? Biological Conservation 124:63-73.

Ferreira Junior, L. G.; Ferreira, N. C. \& Ferreira, M. E. 2008. Sensoriamento remoto da vegetacao: evolucao e estado-daarte. Acta Scientiarum: Biological Sciences 30:379-390.

Fraser, P. J. 2006. Review: depth, navigation and orientation in crabs: angular acceleration, gravity and hydrostatic pressure sensing during path integration. Marine and Freshwater Behaviour and Physiology 39:87-97.

Godley, J. \& BRodie, R. 2007. Effect of summer storms on early life stages of Uca minax, U pugnax and $U$ pugilator in North Inlet Estuary, South Carolina, USA. Marine EcologyProgress Series 342:197-204.

Harley, C. D. G.; Hughes, A. R.; Hultgren, K. M.; Miner, B. G.; Sorte, C. J. B.; Thornier, C. S.; Rodriguez, L. F.; Tomanek, L. \& Williams, S. L. 2006. The impacts of climate change in coastal marine systems. Ecology Letters 9:228-241.

Halpern, B. S.; Walbridge, S.; Selkoe, K.A.; KapPel, C.V.; Micheli, F.; D’Agrosa C.; Bruno, J. F.; Casey, K. S.; Ebert, C.; Fox, H. E.; Fujtta, R.; Heinemann, D.; Lenihan, H. S.; Madin, E. M. P; Perry, M. T.; Selig, E. R.; Spalding, M.; Steneck, R. \& Watson, R. 2008. A global map of human impact on marine ecosystems. Science 319:948-952.
Hendriks, I. \& Duarte, C. M. 2008. Allocation of effort and imbalances in biodiversity research. Journal of Experimental Marine Biology and Ecology 360:15-20.

HiLl, D. L. 2004. Latin America shows rapid rise in S\&E articles. InfoBrief-NSF, 04-336:1-9. Available from: <http:/ /www.nsf.gov/sbe/srs/infbrief/nsf04336/start.htm>, Acesso em: 10.07 .2007

How M. J.; Zeil J. \& Hemmi, J. M. 2007. Differences in context and function of two distinct waving displays in the fiddler crab, Uca perplexa (Decapoda: Ocypodidae). Behavioral ecology and Sociobiology 75:1015-1022

IrfanUlLah, H. M. D. 2006. Algal taxonomy in limnology: an example of the declining trend of taxonomic studies? Hydrobiologia 559:1-9.

Lima-Ribeiro, M. S.; Nabout, J. C.; Pinto, M. P.; Moura, I. O.; Melo, T. L.; Costa, S. S. \& Rangel, T. F. L. V. B. 2007. Análise cienciométrica em ecologia de populações: importância e tendências dos últimos 60 anos. Acta Scientiarum, biological science 29:39-47.

Magurran, A. E. 2004. Measuring Biological Diversity London, Croom Helm. 260p.

ManN, K. H. 2000. Ecology of coastal waters: with implications for management. Oxford, Blackwell Science. $406 \mathrm{p}$.

Martin, J. W. \& Davis, G. E. 2006. Historical trends in crustacean systematic. Crustaceana 79:1347-1368.

MAY, R. M. 1997. The scientific wealth of nations. Science 275:793-796.

Melo, A. S.; Bini, L. M. \& Carvalho, P. 2006. Brazilian articles in international journals on Limnology. Scientometrics 67:187-199.

Nabout, J. C.; De Marco, P.; Bini, L. M. \& Diniz-Filho, J. A. F. 2009. Distribuição geográfica potencial de espécies americanas do caranguejo violinista (Uca spp.) (Crustacea, Decapoda) com base em modelagem de nicho ecológico. Iheringia. Série Zoologia 99: 98-104.

Nobis, M. \& Wohlgemuth, T. 2004. Trend words in ecological core journals over the last 25 years (1978-2002). Oikos 106:411-421.

Odum, W. E.; Woodwell, G. M. \& Wurster, C. F. 1969. DDT Residues absorbed from organic detritus by fiddler crabs. Science 164:576-577.

Padial, A. A.; Bini, L. M. \& Thomaz, S. M. 2008. The study of aquatic macrophytes in neotropics: a scientometrical view of the main trends and gaps. Brazilian Journal of Biology 68: $139-147$

Peters, R. H. 1991. A critique for ecology. Cambridge, Cambridge University. 366p.

Pinto, M. P. \& BinI, L. M. 2008. Vieses geográficos e taxonômicos nas pesquisas sobre seleção de reservas: uma análise quantitativa de 1992 a 2004. Natureza \& Conservação 6:35-45.

Quixabeira, V. B. L.; Nabout, J. C. \& Rodrigues, F. M. 2010 Trends in genetic literature with the use of flow cytometry. Cytometry Part A 77A:207-210.

RosenberG, M. S. 2001. The systematics and taxonomy of fiddler crabs: a phylogeny of the genus Uca. Journal of Crustacean Biology 75:839-869

Sala, E. \& Knowlton, N. 2006. Global marine biodiversity trends. Annual Review of Environment and Resources 31:93-122.

Sмiтh, S. I. 1870. Notes on American Crustacea. No. 1. Ocypodoidea. Transactions of the Connecticut Academy of Arts and Science 2:113-176.

VANTI, N. A. P. 2002. Da bibliometria à webometria: uma exploração conceitual dos mecanismos utilizados para medir o registro da informação e a difusão do conhecimento. Ciência da Informação 31:152-162.

Wishart, M. J. \& Davie, B. R. 2002. Collaboration, conservation and the changing face of limnology. Aquatic Conservation: marine and freshwater ecosystems 12:567-575.

Zeil, J.; Hemmi, J. M. \& Backwell, P. R. Y. 2006. Fiddler crabs. Current biology 16:R40-R41.

Recebido em novembro de 2010. Aceito em dezembro de 2010. ISSN 0073-4721

Artigo disponível em: www.scielo.br/isz

Impresso e distribuído em 2011. 